\title{
An Investigation into the Impacts of Climate Change on Anthro- pogenic Polluted Coastal Lagoons in Ghana
}

\author{
Isaac Boateng ${ }^{a}$ Steve Mitchell ${ }^{b}$ Fay Couceiro ${ }^{b}$ Pierre Failler $^{c}$ \\ a. Department of Construction and Wood, University of Education, Winneba, Ghana; \\ b. School of Civil Engineering and Surveying, University of Portsmouth, Portsmouth, UK; \\ c. Portsmouth Business School, University of Portsmouth, Portsmouth, UK
}

CONTACT Isaac Boateng isaac.boateng@uew.edu.gh

\section{ABSTRACT}

This paper discusses the impacts of Climate Change and anthropogenic activities on coastal lagoons in Ghana. Ghana's coastal lagoons provide unique ecosystem services. However, they are highly fragile and vulnerable to natural processes and anthropogenic activities. Climate Change impacts, such as increased temperatures, sea-level rise, storm surge and increased precipitation are likely to have ecological damage to lagoon ecosystems as a result of erosion, submergence of lagoon barriers, flooding and drying of the surrounding wetlands. Field observation, Geographic Information System modeling were among the methodology applied. The paper identified that anthropogenic activities and Climate Change would combine to have a serious future impact on lagoon ecosystems. Particularly, increased rainfall-induced flooding from the hinterland may be very injurious to the lagoon ecosystem, since the flood water may carry not only nutrients but also various contaminants and solid plastic waste generated by human activities around lagoons catchment into the lagoon channels. Besides, due to the barriers across most lagoon inlets, such polluted runoff water may not be able to flush out to sea, thus impacting negatively on the water quality of the lagoons. The paper proposes some adaptation strategies and recommends the early implementation of Climate Change adaptation strategies, coastal lagoon management measures to prevent potential future destructive impacts.

Keywords: Anthropologic pollution; climate change; coastal adaptation and Ghana's coast; Coastal Lagoons; water quality

\section{FUNDING}

This research project was funded by the Research Development Fund of the University of Portsmouth, UK.

\section{Introduct on}

Coastal lagoons are shallow coastal water bodies that are separated from the ocean by barriers. They are mostly connected at least intermittently to the ocean by one or more restricted inlets (Kjerfve 1994). According to the Millennium Ecosystem Assessment (2005), lagoons provide ecosystem services, which include provisioning services (food and water); regulating services (flood and disease control); cultural services (spiritual, recreational, and cultural benefits); and supporting services, (nutrient cycling) that maintain the conditions for life on Earth. Coastal lagoons in Ghana present a unique environment, habitats and provide ecosystem services (Entsua-Mensah 2002). Glavovic (2000) has estimated that coastal lagoon systems in Africa provide goods and services above US\$500 billion annually. However, lagoons are highly fragile and vulnerable to both natural processes and anthropogenic activities. Urbanization and land-based pollution have had significant impacts on water quality, hydrodynamics, geomorphology and the biodiversity of coastal lagoons. 
West African lagoons, including those in Ghana, suffer from land-based pollution (Ukwe, Ibe, and Sherman 2006), which weaken their ability to produce the natural services, their resilience and their capacities to mitigate and adapt to Climate Change (CC) (Intergovernmental Panel on Climate Change [IPCC] 2014). The effects of CC such as increased temperatures, sea-level rise (SLR), increased intensity of storms and precipitation are likely to have the most severe impacts on lagoon ecosystems (Ranasinghe 2016). These impacts threaten not only the goods and services obtained from the coastal systems but also the life and properties of coastal communities.

The world's coastlines are shaped by mean sea level, wave conditions, storm surge, and river flows. CC and anthropogenic driven variations of these environmental forces will inevitably have a profound effect on the coastal zone (Ranasinghe 2016; Nicholls et al. 2014). The effects of CC would impact on coastal lagoons and exacerbate the ecological damage as a result of flooding, erosion and submergence of lagoon barriers. These could disrupt the productivity of ecosystem services of coastal lagoons and potentially jeopardize livelihoods of coastal communities that subsist on lagoon resources.

Nonetheless, local knowledge on the impacts of $\mathrm{CC}$ on coastal lagoons and its implications for environmental management is very limited in Ghana. There is a need to conduct detailed investigations into the impacts of CC on Ghana's coastal lagoons to ascertain the possible local impacts to facilitate the development of adaptation policies to reduce the effects. This paper seeks to investigate Ghana's coastal lagoons to ascertain general impacts and to identify key driving forces to enable the development of adaptation and mitigation strategies. The paper focuses on eight (8) selected coastal lagoons located between Tema and Winneba (Figure 1).

Figure 1. A map of Ghana showing the case study area and a list of sampled lagoons.

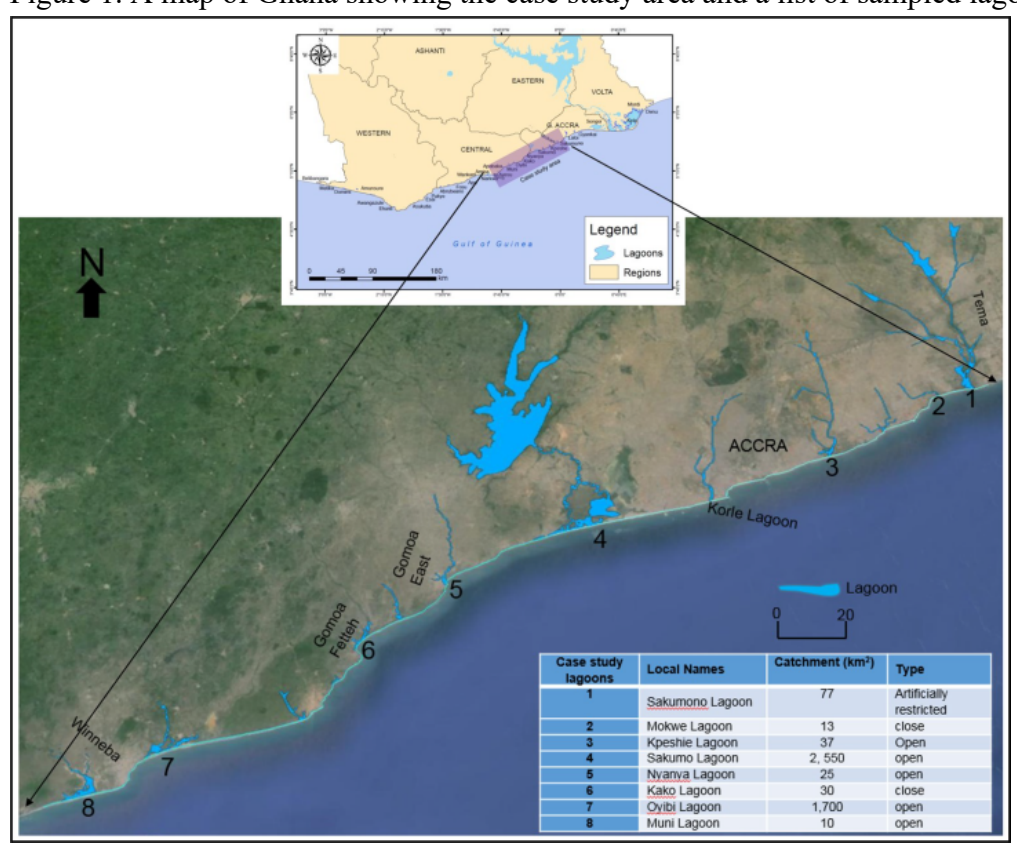

\section{Study area}

The coastal zone of Ghana, defined as the area below the $30 \mathrm{~m}$ contour, represents about $7 \%$ of the land area of $238,533 \mathrm{~km}^{2}$ (Boateng 2009) and has about 50 coastal lagoons interspersed along the $540 \mathrm{~km}$ coastline. Lagoons in Ghana are known to provide valuable resources such as fish, crabs and reeds for weaving mats for local peasant fishermen consumption and sale at the national and international markets. In some areas, vegetables are grown upstream of the lagoons in sandy garden beds irrigated with fresh lagoon water. Salt evaporated ponds are created along the banks of some salty lagoons for commercial production of salt (Affam and Asamoah 2011). In fact, lagoons are among Ghana's most valuable ecosystems providing critical habitats for many fish and wildlife resources. 
The study area represents a medium energy environment. It comprises an embayment coast of rocky headlands and sand bars with spits enclosing coastal lagoons. The geomorphology of the study area is influenced by sediment delivered from a series of north to south draining rivers that discharge sediment to the sea through the lagoons. Sediments tend to be confined within embayment between rocky promontories. The tidal range in the Gulf of Guinea is relatively low at 1-2 m, though storm surges are common (Boateng 2012a). The tidal range in Ghana is low and varies little between spring tide $(1.32 \mathrm{~m})$ and neap tides $(0.58 \mathrm{~m})$ (Mitchell, Boateng, and Couceiro 2017) and therefore have less influence on coastal processes except within tidal inlets. As a result, coastal lagoons in Ghana are either closed or open to the sea. While some are permanently closed to the sea, others are seasonally open to the sea (Mitchell, Boateng, and Couceiro 2017). Figure 1 shows the type (open or close) of sampled lagoons and their catchment sizes.

\section{Material and methods}

A preliminary investigation was conducted on the whole shoreline of Ghana. This involves a review of literature, historical maps and satellite images. This investigation led to the identification of the case study area and the selection of the eight sampled lagoons (Figure 1). The sample lagoon selection depended on practical matters such as access, type of lagoon (open and closed), a mix of rural and urban lagoons and their suitability for monitoring.

It was identified that, relevant data on pollution, geomorphological processes and flood risks that might help critical analysis of CC impacts were fragmented and very incomplete. To overcome this challenge, a major field investigation was conducted to collect key data to develop a more detailed understanding. The fieldwork offered the opportunity to observe and assess the various coastal developments and activities that might be at risk due to the impacts of $\mathrm{CC}$ and associated SLR.

The preliminary field sampling of lagoons 1 to 8 (Figure 1) was done in September 2015 (rainy season). Various observations on the field at each site were recorded on field datasheet and others were photographed. The field data sheet for each site was assessed and compiled into site Proformas (e.g., Table 1). The site proformas provide a holistic view of the key processes and issues at each lagoon inlet. The solid waste pollution (coastal litter) at each inlet was observed, photographed and compared amongst the inlets. Solid waste pollution observed were also assessed and evidence was recorded. The water quality results are presented in Tables 2 and 3. The map showing the sample location of the lagoons and also presented as Figure 2.

Figure 2. Lagoons sampled locations.

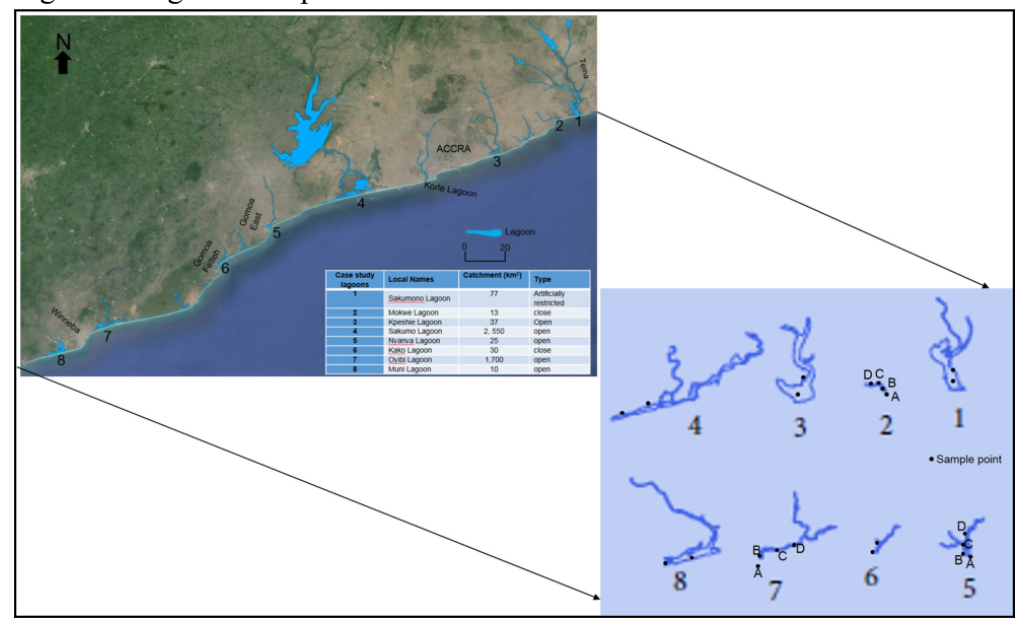

Table 1. Mokwe Lagoon: Site Proforma (14/09/2015) 14:00. 
A general overview of the site: Mokwe lagoon is an inlet which dissects the soft sandstone cliff with eroded hard limestone at the shore area (see satellite image and map below). The inlet is very close to the Maritime University in Nungua a suburb of Accra and has mangroves at its banks. The site is polluted by lots of land-based debris (photo 2).
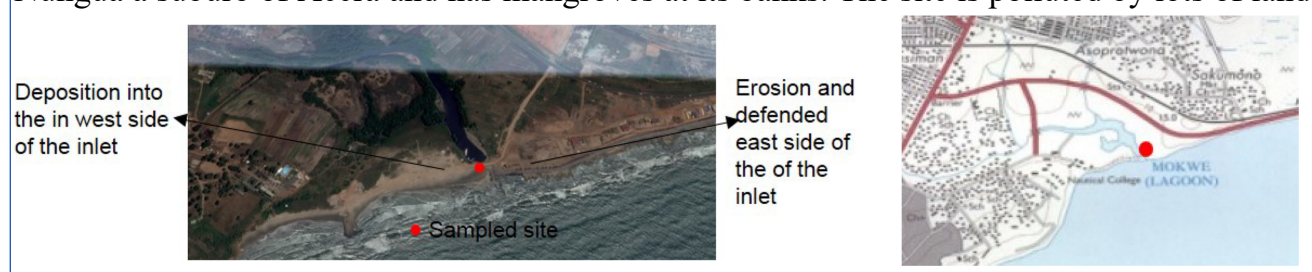

Inlet morphology and Littoral Drift: The inlet has imbalanced flood and ebb-tidal exchange. The strong flood tidal energy has pushed sediment into the inlet at the western bank of the inlet and the weak ebb tidal flow discharge into the sea at the eastern side of the inlet, which has less sediment deposit. The widening of beach width from west to east and the diversion of the mouth toward the east were a clear indication of the west to east littoral drift direction. The inlet has more sediment deposition up-drift than the down-drift as significant amounts of the sediment are stored in the inlet. The inlet may be classified as closed since field evidence shows no significant daily flood and ebb-tidal exchange.

Sediment Transport Information: The erosion of the beach and the sandbank at the west, longshore drift into the area and the discharge of fluvial sediment by the lagoon were the sources of sediment into the area. Wave processes, tidal exchange and the low barrier across the inlet (Photo 2) facilitate the transport of littoral sediment across the inlet. Some of the littoral sediment transported into the inlet are stored on the western bank of the inlet as sandbank. The sediment stored in and around the inlet is carried back into the littoral zone either by a storm or heavy rainfall in the catchments area that flood the banks of the lagoon channel.

Geomorphologic Information: The beach at this site is wide at the west and narrow at the east. It is sandy and has a dissipative slope. The inlet of the lagoon is flanked by colonized sandbank and mangroves at the east. The backshore of the lagoon has mangrove flood plains. The inlet is drift aligned.

Physical Processes: The site has a medium energy type. The wave period was about 6-9 per minute at the point of observation. While the beach up-drift of the inlet is accreting and has colonized sandbank, the beach and cliff downdrift is severely eroding and has been recently defended with rock armor. The flood and the ebb tide seem relatively imbalance and thus creating a diverted lagoon mouth toward the east and also confine the ebb-tidal flow in a small channel (Photo 3). The area is an erosion threat zone.

Management Information: The area behind this site is an urban settlement. The properties of the Maritime University on the west and the Tema-Accra trunk road on the east are threatened by erosion. The authorities have resorted to the use of rock amour and a groin (Photo 1) to protect some of the weakest points along the shoreline. The issue of coastal debris at this site is a critical management problem that should be considered seriously.

Other Photo(s):
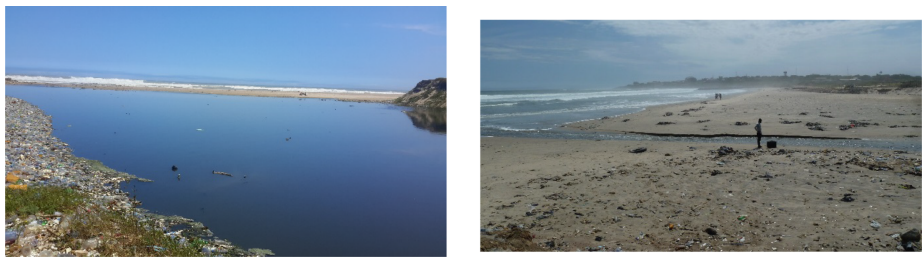

inlet Photo 3: Ebb tidal channel

Photo 2: A low barrier across the

Table 2. Climate change impact risk assessment.

\begin{tabular}{|c|c|c|c|c|c|c|c|c|c|}
\hline \multirow[t]{2}{*}{ Lagoon } & Nitrate & Nitrite & Total Ammonia & Phosphate & $\mathrm{DO}$ & DIN & \multicolumn{2}{|c|}{ Temp Salinity $\mathrm{pH}$} & Turbidity \\
\hline & $\mathrm{mg} / \mathrm{L}$ & $\mathrm{N}$ & $\mathrm{mg} / \mathrm{L} \mathrm{N}$ & $\mathrm{mg} / \mathrm{L} \mathrm{P}$ & $\mathrm{mg} / \mathrm{L}$ & $\mathrm{g} / \mathrm{L} \mathrm{N}$ & ${ }^{\circ} \mathrm{C}$ & PSU & NTU \\
\hline 1.Sa & 11.80 & 0.70 & 31.00 & 5.41 & 16.58 & 43.50 & 29.7 & 2.18 .2 & 34.9 \\
\hline 2.Mokwe & 11.40 & 0.70 & 49.00 & 5.97 & 3.73 & 61.10 & 29.9 & 10.67 .5 & 658.6 \\
\hline
\end{tabular}




\begin{tabular}{|c|c|c|c|c|c|c|c|c|c|}
\hline \multirow[t]{2}{*}{ Lagoon } & Nitrate & Nitrite & \multirow{2}{*}{\multicolumn{2}{|c|}{$\begin{array}{c}\text { Total Ammonia Phosphate } \\
\mathrm{mg} / \mathrm{L} \text { N } \mathrm{mo} / \mathrm{L} P\end{array}$}} & \multirow{2}{*}{\multicolumn{2}{|c|}{$\begin{array}{c}\mathrm{DO} \\
\mathrm{mg} / \mathrm{L} \\
\mathrm{mg} / \mathrm{L} \mathrm{N}\end{array}$}} & \multicolumn{3}{|c|}{ Temp Salinity pH Turbidity } \\
\hline & \multicolumn{2}{|c|}{$\mathrm{mg} / \mathrm{L} \mathrm{N} \mathrm{mg/L} \mathrm{N}$} & & & & & ${ }^{\circ} \mathrm{C}$ & PSU & NTU \\
\hline 3.Kpeshie & 8.30 & 0.22 & 20.00 & 2.81 & 1.62 & 28.52 & 24.4 & 32.67 .1 & 8.6 \\
\hline 4.Sakumo & 14.60 & 0.29 & 6.00 & 0.66 & $7.97 \mid$ & 20.89 & 26.7 & 36.37 .8 & 8.8 \\
\hline 5.Nyanya & 8.72 & 0.01 & 42.00 & 0.06 & 6.44 & 50.73 & 24.4 & 36.67 .7 & 20.2 \\
\hline 6.Kako & 3.02 & 0.02 & 1.30 & 0.07 & 7.49 & 4.34 & 28.4 & 22.77 .8 & 7.1 \\
\hline 7.Ayensu & 7.48 & 0.01 & 2.90 & 0.07 & 6.11 & 10.39 & 26.5 & 6.87 .5 & 10.6 \\
\hline 8.Muni & 3.02 & 0.01 & 1.30 & 0.16 & 7.29 & 4.33 & 28.4 & 38.47 .8 & 77.3 \\
\hline MAC EU & 5.60 & 0.06 & 0.40 & 0.10 & 7.00 & 4.00 & 28.0 & 9.0 & \\
\hline
\end{tabular}

September 14-18 2015

Table 3. Results of water quality assessment of the three intensive lagoons

\begin{tabular}{|c|c|c|c|c|c|c|c|c|c|c|}
\hline Site & Nitrate & Nitrite & Total Ammonia 1 & Phosphate I & $m g / L$ & $D I N$ & $F C(\mathrm{ml})$ & Temp & Salinit & PH Turbidity \\
\hline & $\mathrm{mg} / \mathrm{L} \mathrm{N}_{1}$ & $\mathrm{mg} / \mathrm{L} \mathrm{N}$ & $\mathrm{mg} / \mathrm{L} \mathrm{N}$ & $\mathrm{mg} / \mathrm{L} \mathrm{P}$ & & $\mathrm{mg} / \mathrm{L} \mathrm{N}$ & & ${ }^{\circ} \mathrm{C}$ & PSU & NTU \\
\hline Mokwe A & 2.51 & 0.012 & 0.5 & 0.0693 & 7.35 & 3.02 & 550 & 25.9 & 36.8 & 8.112 .3 \\
\hline Mokwe B & 1.4 & 0.03 & 35 & 13.035 & 1.01 & 36.43 & 20000 & 27.1 & 3.4 & 8.055 .5 \\
\hline Mokwe C & 0.9 & 0.048 & 45 & 16.599 & 0.91 & 45.95 & 20000 & 27.2 & 2.1 & 7.850 .3 \\
\hline Mokwe D & 0.735 & 0.03 & 40 & 15.675 & 0.30 & 40.77 & 20000 & 24.7 & 3.7 & 7.451 .5 \\
\hline Nyanya A & 4.79 & 0.009 & 2 & 0.1221 & 6.49 & 6.80 & 1680 & 26.8 & 36.0 & 7.9396 .8 \\
\hline Nyanya B & 3.43 & 0.025 & 25 & 0.0924 & 5.40 & 28.46 & 2460 & 27.2 & 35.3 & 7.9965 .2 \\
\hline Nyanya C & 5.35 & 0.15 & 9.5 & 0.1848 & 5.16 & 15.00 & 280 & 28.3 & 29.3 & 7.813 .6 \\
\hline Nyanya D & 4.12 & 0.32 & 6.5 & 0.2937 & 4.41 & 10.94 & 350 & 27.5 & 27.2 & 7.941 .2 \\
\hline Ayensu A & 2.96 & 0.002 & 3.6 & 0.0594 & 6.52 & 6.56 & 36 & 27.9 & 35.9 & 7.8308 .5 \\
\hline Ayensu B & 4.88 & 0.002 & 2.1 & 0.0627 & 6.82 & 6.98 & 720 & 27.7 & 28.9 & 7.912 .7 \\
\hline Ayensu C & 5.3 & 0.002 & 2.8 & 0.0891 & 6.32 & 8.10 & 450 & 28.8 & 34.0 & 7.77 .9 \\
\hline Ayensu D & 2.83 & 0.007 & 2.2 & 0.066 & 5.92 & 5.04 & 110 & 28.6 & 32.4 & 7.411 .5 \\
\hline MAC EU & 5.60 & 0.06 & 0.40 & 0.10 & 7.00 & 4.00 & 2000.0 & 28.0 & & 9.0 \\
\hline
\end{tabular}

Mokwe - Lagoon 2, Nyanya - Lagoon 5, Ayensu - Lagoon 7

January $25^{\text {th }} 272016$

Based on the outcome of the preliminary survey, three lagoons were selected for intensively sampling in January 2016 (dry season). The intensive sampling was to develop a detailed understanding of the lagoons and the distribution of the pollution from the coastal zone to further upstream (Table 3).

Figure 2 a map show the location of Lagoon samples site

The potential CC impacts on the sampled coastal lagoons were assessment using literature review, Geographic Information System (GIS) and field observations focusing on two indicators (exposure and hazard) that characterized key coastal lagoon vulnerability. These indicators were observed during the field survey, compiled in the site proformas and extracted for the $\mathrm{CC}$ impact assessment. The physical processes along the shoreline and land use at the backshore were also considered in the assessed to enable the identification of life and properties at risk to the impacts of CC.

The GIS analysis and modeling of the impact of rising sea level on Ghana's coastal lagoon were also assessed. The assessment was done following 2100 Sea-level rise (SLR) predictions and vulnerability assessment (Tol, Klein, and Nicholls 2008; IPCC 2014, NASA 2015). SLR and rainfall-induced flood scenario maps were created. The maps 
were used for comparative assessment of the sensitivity of the case study area to different sea levels predictions and land-based flood risk. There are large uncertainties in the prediction of CC. Therefore, any conscientious effort to assess CC impacts on any coast should consider the quantification of the range of uncertainty associated with model predictions (Ranasinghe 2016). This can be achieved by assessing different scenarios. This approach is similar to Hallegatte et al. 2011 and Boateng 2012a. First, Geo-referenced $15 \mathrm{~m}$ panchromatic bands of Shuttle Radar Topographic Mission (SRTM) data of Ghana were acquired from the Global Land Cover Facility and used for the assessment of the flood risk based on the predicted future sea levels and potential storm levels. The data were opened in ERDAS Imagine overlaying 2002 topographic map of Ghana with a scale 1:50,000. The coordinates and spot heights of this topographic map were used for coordinates and height values validation of the SRTM data. Then using ERDAS Virtual GIS, three flood layers were created on the image. They are:

1. One meter, (predicted global mean sea-level rise by 2100: IPCC 2014; DeConto and Pollard 2016),

2. Two meters (the upper limit of global mean prediction for sea-level rise by 2100; Pfeffer, Harper, and Neel 2008; Jevrejeva, Grinsted, and Moore 2014), and

3. Five meters (a long term scenario involving catastrophic melting of West Antarctic ice sheet and extreme storm event; Vaughan 2008; DeConto and Pollard 2016). A local deviation of $(+/-0.2 \mathrm{~m})$ was considered in all the predicted SLR scenarios.

To assess the effects of anthropogenic pollution on the water quality of the lagoons, the water quality of all the lagoons were sampled during two field campaign. Total and fecal coliform counts were measured using membrane filtration and incubation on a membrane lauryl sulfate broth saturated pad at 36 _C and 44 C respectively using the ELE Paqualab 50, a portable field kit made for water quality testing. The ELE Paqualab 50 is composed of a filtration unit which can be sterilized in the field and two incubation chambers set to the required temperatures. Total coliform counts are not shown here because they were above the threshold for counting in nearly all cases. These assessments were conducted at the back of a track that was used for the fieldwork.

The water parameters: temperature, salinity, $\mathrm{pH}$, turbidity and dissolved oxygen, were assessed in situ using a YSI Pro DSS multiparameter sonde. Salinity was measured using the practical salinity scale, and is, therefore, quoted without units. The sonde when deployed logged data every 2 seconds for 30 seconds and the data were averaged over that period. Five hundred (500) $\mathrm{ml}$ water samples were also taken and $100 \mathrm{ml}$ were filtered on-site then stored in a cool box for nutrient analysis (maximum storage time $8 \mathrm{hrs)}$ ). The remaining $400 \mathrm{ml}$ was stored in the cool box unfiltered and used for microbial analysis after the fieldwork (the same day). Nitrate, nitrite, ammonia and soluble reactive phosphorus were determined color metrically using Palintest photometer tablet reagents and the Palintest 7500 photometer. Tablet reagents were; Nitrate (Nitratest ${ }^{\mathrm{TM}}$ ) $0-20 \mathrm{mg} / \mathrm{L} \mathrm{N}$, Nitrite (Nitricol ${ }^{\circledR}$ ) 0-0.5 mg/L N, Ammonia 0-1 mg/L $\mathrm{N}$, Phosphate LR 0-4 mg/L PO4. Nitrite data are not shown individually but are used in the calculation of dissolved inorganic nitrogen (nitrate + nitrite + ammonia) as applied by Mitchell, Boateng, and Couceiro (2017).

All the water quality parameters were compared to the European Union (EU) Maximum Allowable Concentration (MAC) since there is no water quality standard in Ghana or West Africa. It was identified that except for Nitrite, $\mathrm{pH}$ and temperature that was almost the same as the EU MAC, all the other parameters measured showed significant disparity from the MAC in EU. The detailed outcome of the water quality assessment has been presented in (Tables 2 and 3). However, the potential effects of spillage of the polluted lagoons water under climate variability have been presented in the discussion.

\section{Results}

\section{Field observations}

The results of the field observations at each of the eight (8) sampled lagoon inlets were summarized in eight site proformas (see an example, Table 1). The proformas combine text, labeled site photographs, maps and satellite images to give live coverage of each site sampled in the field. This facilitates the consideration of key field observations in the final results, analysis and discussion. It also provides evidence to the authors about processes and management problems being discussed at each sampled location. To reduce the size of the paper only one site proforma is presented here as an example to readers. 
First of all, the preliminary survey identified that all the lagoons sampled have mangroves at their fringes, except Sakumono. The mangroves showed signs of depletion, but lagoons 5 and 8 had the highest rate of depletion (Figure 3 ). The cutting of the mangroves to make room for salt pans and the use of mangrove stems as a source of fuel for smoking fish by the local fishmongers were identified to be among the current causes of mangrove depletion.

Figure 3. Coastal Mangroves at the fringes of the sampled Lagoons.

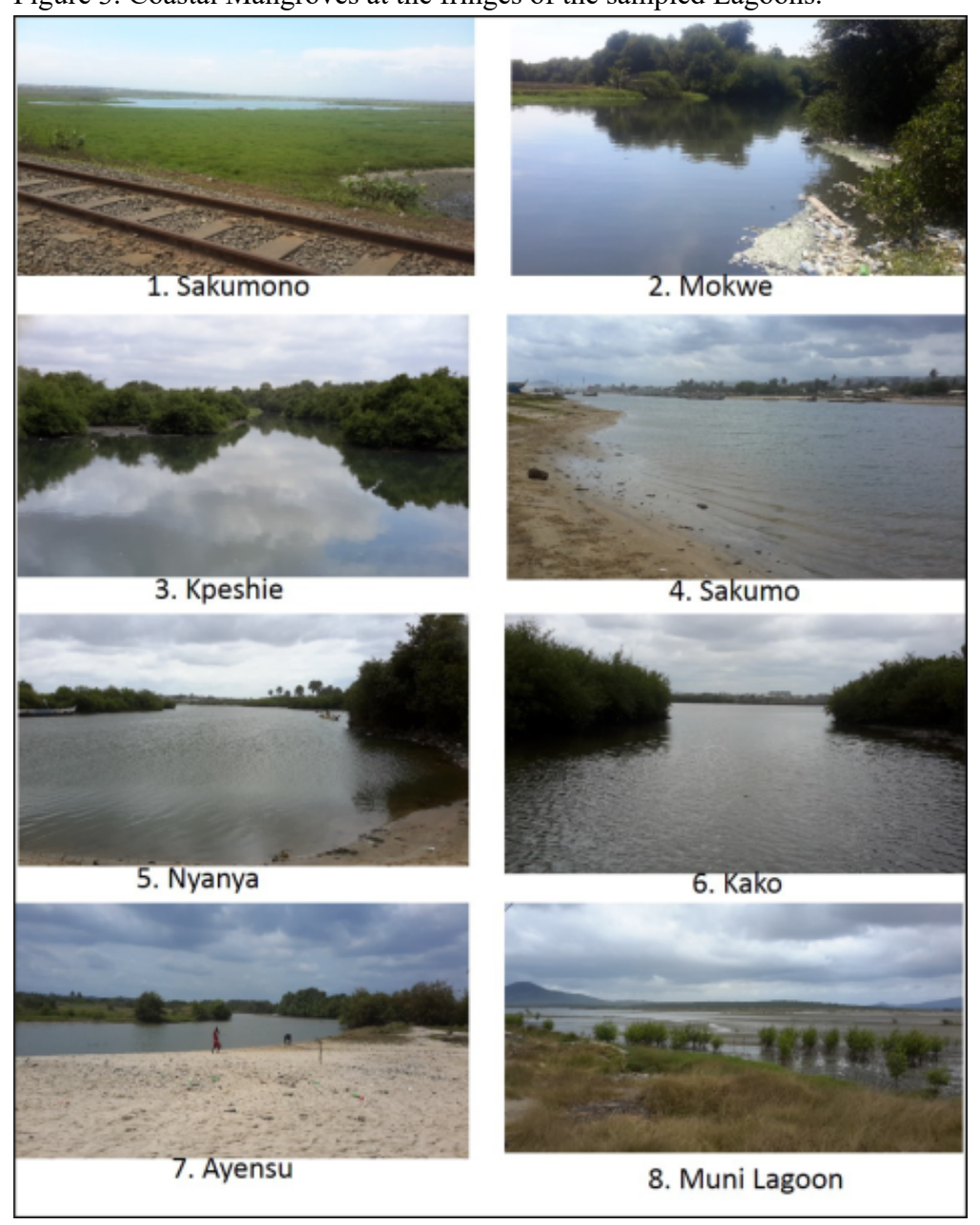

Secondly, all the lagoons were identified to be polluted with various forms of solid waste (coastal debris) from anthropogenic sources and the level of the pollution decreases as one moves away from the urban coastline of Accra. Mokwe lagoon was identified to be the most polluted lagoon (Figure 4). It was identified that about $80 \%$ of the coastal debris comprises plastics in the form of water and beverage bottles, sachet water bags and polythene bags. The remaining $20 \%$ comprises the following: car tyres, electronic waste, textiles, glass bottles, polystyrene and various forms of footwear. The waste pollution was already having a negative impact on fishing in the area and could potentially enter the food chain in the form of microfibre of plastics, polystyrene, textile and other none biodegradable waste materials (Figure 5).

Figure 4. Solid waste pollution of coastal lagoons in Ghana (photos 1-8 shows sampled lagoons in a clockwise direction and a zoomed version of Lagoon 2). 

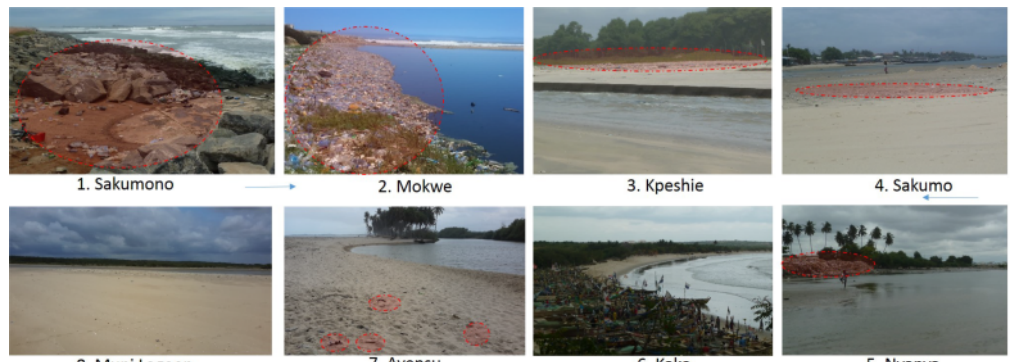

3. Kpeshie

4. Sakumo

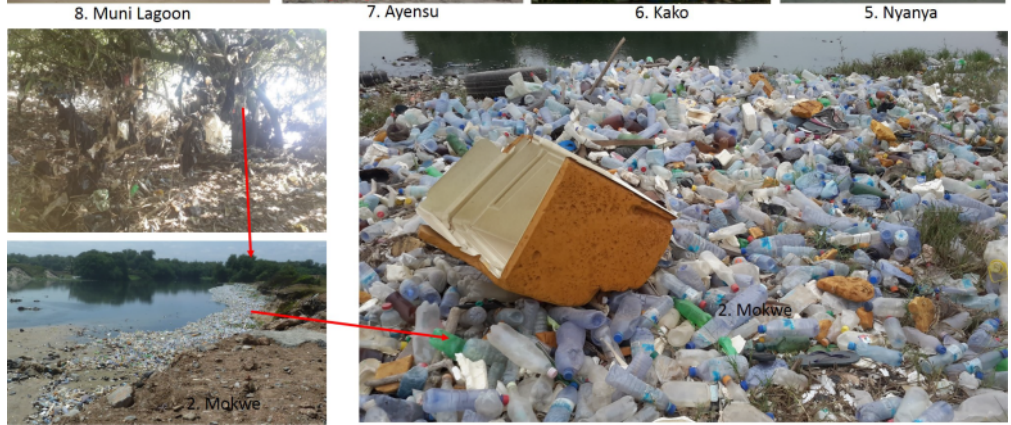

Figure 5. Evidence of crab harvesting from the rubbish contaminated area and how plastic litters are polluting fish caught from the sea for consumption from lagoon 2 and 7.

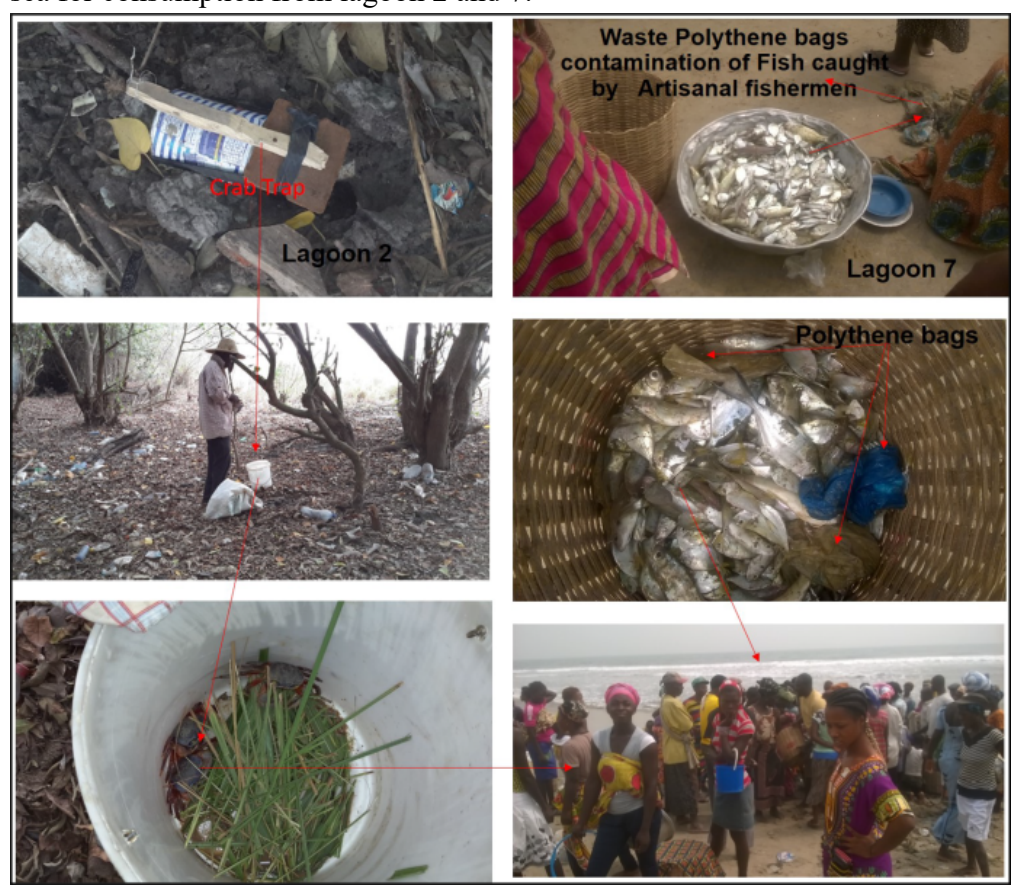

Thirdly, we observed different economic activities at the inlets. Some of the main activities identified as the uses of the inlets include the artisanal fishing harbor, market place, salt mining and tourist resorts (Figures 5). We also found vegetable farming upstream of some of the lagoons. Most of these activities are already at risk of flooding and erosion and a few of them have some form of defenses. Furthermore, we observed that all the lagoons have sandy barriers with varying dimensions across their inlets and have limited tidal exchange

Finally, evidence of coastal erosion was observed at all the inlets, particularly, lagoons 5 and 8 (Figure 6). Erosion rate at the case study area ranges between $1.5 \mathrm{~m}$ and $2.3 \mathrm{~m} /$ year (Appeaning-Addo, Walkden, and Mills 2008; Boateng (2012b). The causes include natural processes (soft geology, rising sea level and episodic storm waves) and an- 
thropogenic causes (mining beach sand for construction (Figure 6), dams on sediment donor rivers and the "knockon-effect" of uncoordinated coastal defenses) (Boateng, 2010).

Figure 6. Different uses of coastal lagoon inlets in Ghana: scenes from sampled lagoons.

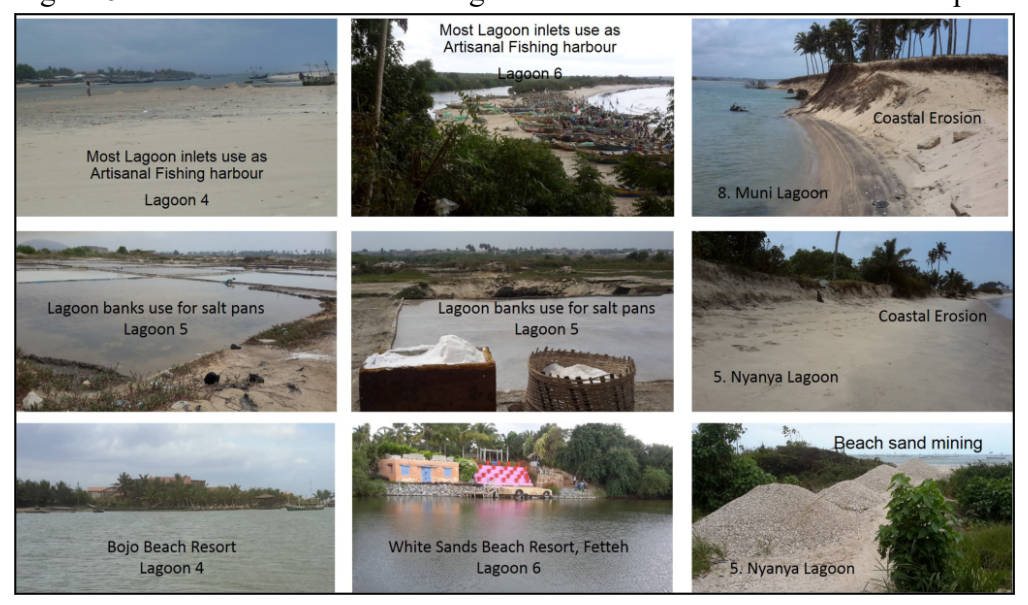

\section{Lagoon water quality assessment}

Nitrate and ammonia concentrations were identified to be higher during the rainy season than the dry season. The nitrate concentrations for most of the lagoons might be of some concern only in the rainy season than the dry season (Tables 2 and 3).

The total ammonia concentrations were identified to be of significant concern. The eight lagoons sampled in the dry season, showed 'bad' water quality as all the eight were above the EU MAC (Table 2). Higher concentrations of ammonia are toxic to fish and macroinvertebrates, with sewage waste being the key source of ammonia in rivers, however, agricultural sources cannot be eliminated. The concentrations of total ammonia found in most of the sampled lagoons are likely to harm their ecology and the fishing industry along the coast (see Lagoons 5 and 7), where the impact of this deleterious effect must be felt most. Another major implication of large nutrient inputs into water bodies is the increased likelihood of eutrophication. In coastal areas, this is often measured as dissolved inorganic nitrogen (nitrate + nitrite + total ammonia, known as DIN) and Soluble Reactive Phosphorus (SRP). Due to the expected dilution factor, the EU guidelines for DIN in transitional waters and coastal bodies are lower than the nitrate or ammonia standards that apply in rivers. Table 2 shows that in all the eight (8) cases the lagoons fell into the 'bad' water quality category for DIN, this might be the result of the very high total ammonia concentrations. The large concentration of DIN shows that the sampled lagoon (particularly the sampled sites) are at risk of eutrophication. Though we did not analyze chlorophyll-a when filtering water samples for nutrient analysis, evidence for eutrophication in clogged, green filters were identified at Lagoons 1 to 3) (Sakumono, Mokwe and Kpeshie lagoons respectively - all in Accra). This discrepancy may be a result of the relatively low concentrations of Soluble Reactive Phosphorus (SRP) (Table 2) in Lagoons 4 to 8 in comparison with the high DIN and phosphorus may be a limiting factor for phytoplankton growth at these sites. Anecdotally, the clogged green filters were only seen at Lagoons 1 to 3 where the SRP was 10 to 100 times greater than that observed further west. Although SRP concentrations are generally in the good-to-moderate range compared to EU rivers (Tables 2 and 3), it might be considered prudent for the Water Management Authorities in Ghana to bring in legislation to maintain these levels now rather than allowing them to increase further and bring with them the many problems associated with eutrophication of coastal waters. Dissolved oxygen concentrations are shown in Tables 2 and 3 in most cases range between good and high (EU) status despite temperatures being higher in Ghanaian waters (Table 2) than in waters in northern Europe, which would have the effect of reducing the solubility of the oxygen. A notable exception to this is Lagoon 2 where concentrations are very low and heading toward anoxia. The low oxygen and high DIN and SRP concentrations here strongly suggest that eutrophication is occurring. It can be expected that virtually no fish or aquatic macro-invertebrates would be able to survive in these waters for long and if the oxygen concentrations do fall the site could be affected by poor odor due to a shift to anaerobic conditions. This would certainly have an impact on the local users of the water, including vegetable farmers and small business owners who may wish to purchase land adjacent to the lagoons to build beach resorts, for example. 
The September 2015 sampling of the lagoons did not assess fecal coliform (Table 2). However, fecal coliform data were collected during January 2016 (Table 2). Fecal coliform counts in warmer waters tend to be indicative of the presence of bacteria rather than being DNA-specific (Mitchell et al. 2016). Table 3 shows that Lagoon 2 has a much greater concentration than Lagoons 5 or 7. Samples taken for fecal coliforms from Lagoons 5 and 7 are below the EU threshold. These lagoons also have a lower DIN and SRP concentration. These differences may be due to the greater flushing they receive from seawater or because they receive less sewage than Lagoon 2.

The results of salinity and turbidity showed in Tables 2 and 3 reveal a range of values, though the results for temperature and $\mathrm{pH}$ are more predictable and less variable. Lagoon 2 shows a lower salinity in the January sample than in September, reflecting the dynamic nature of the inlet allowing different degrees of flushing to take place; the inlet was also in a different position in January compared with September. Lagoon 7 is characterized by a higher salinity in January, due to the lower freshwater flow. Results for turbidity in Lagoon 5 and 7 show large differences which may be a result of the activities of fishermen immediately before the visit.

\section{Climate change impact assessment}

It was identified that all the lagoons are exposed and sensitive to the impacts of $\mathrm{CC}$. Indeed, some are already experiencing the impacts of CC. Among the physical factors found to have made the lagoon inlets vulnerable are soft geology, low elevation (between $0 \mathrm{~m}$ and $5 \mathrm{~m}$ above sea level) and the erosion of lagoon barriers (Figure 6). Regarding CC, rising temperature and sea levels, storm waves and flash floods (IPCC 2014; Boateng 2012a) were found to be the key factors having large impacts on the lagoon wetlands, life and properties at the backshore of the case study area. Anthropologic activities, including beach sand mining, coastal development on vulnerable areas and uncoordinated defenses were found to have exacerbated the impacts. The risk to life, properties, economic activities, infrastructure and the natural systems both at the inlets and at the backshore vary significantly. In particular, lagoons 1,2 , 3 and 4 were found to be highly at risk because of low elevation, soft geology and significant infrastructure at the backshore. However, lagoons 5, 6, 7 and 8 were identified to have less risk because developments at the backshore are located on relatively hard geology (limestone) and have higher elevation.

It is estimated that all the sampled inlets may be vulnerable to the impacts of the $1 \mathrm{~m}$ sea-level rise (PSMSL 2013; IPCC 2014) due to low elevation. The phenomena may affect all the lagoons and will increase the flood risk to recreational and residential properties as well as other commercial activities at the backshore of the lagoon inlets.

The rising sea levels under CC may increase the destructive effect of waves and storm surge on the sandy barriers and spits at the lagoon inlets. This may increase tidal exchange, which may improve water quality, but increase salinity and salt intrusion into aquifers. The increased intensity of tide, wave and storm may increase erosion and flooding and thus threaten life, properties and socio-economic activities such as fishing, salt mining in Lagoon 5 and beach tourism in Lagoon 4, 6 and 7. Storm surge may also destroy the natural systems including the mangroves. Also, increased precipitation and flash floods associated with CC may destroy vegetable farms, aquaculture ponds, salt production ponds and settlement at the backshore of the lagoons. This may threaten life, properties and economic activities in the flood plains of the lagoons.

All the lagoons are exposed to the impacts of CC and some are already experiencing the negative effects. However, the impacts vary from one lagoon to another. It has been identified from our field survey that all the lagoons are at risk of the threat of human development, which tends to aggravate $\mathrm{CC}$ impacts. The shoreline may be exposed to increased erosion thereby moving the present inlet positions landwards. However, water quality may improve as a result of the increased tidal exchange, freshwater and flushing out of the polluted lagoon water to the sea and possibly open closed lagoons and widening their inlets to allow more tidal exchange.

Of particular concern regarding the flood risk assessment is the possibility that water contaminated with fecal waste could flood onto farmland. The presence of fecal coliforms is also an indicator that other pathogens from human waste may be present and if the crop is grown is collected and consumed raw, there are serious health implications to the consumers. In the 1989 WHO guidelines for using treated wastewater in agriculture and consequently Blumenthal et al. (2000) recommendations to update the WHO guideline both suggest a maximum of 1000 fecal coliform counts per $100 \mathrm{ml}$ in water used for the irrigation of crops likely to be eaten raw. Three lagoons $(2,5$ and 7$)$ were a test for fecal coliforms and both lagoons 2 and 5 were above this limit. The extent to which dangerous bacteria survive on plants or in the soil is not completely understood, but factors influencing fecal bacteria survival include mois- 
ture, soil type, temperature, $\mathrm{pH}$, manure application rate, nutrient availability, and competition (Jamieson et al. 2002; Stoddard, Coyne, and Grove 1998). As such it is also important to ensure that any crops inundated by flooding be thoroughly dry before harvest and that increasing the time between the flood receding and harvesting to lower the risk of contamination.

\section{Gis assessment of vulnerability to SLR and flood risk}

The GIS assessment of the CC induced flood risk (Figures 7 and 8) was done to ascertain the sensitivity and the vulnerability of the land use at the backshore of the study area as well as the shoreline evolution under the three sealevel scenarios ( $1 \mathrm{~m}, 2 \mathrm{~m}$ and $5 \mathrm{~m})$ by 2100 .

Figure 7. Assessing the impact of Sea Level Rise on the case study area.

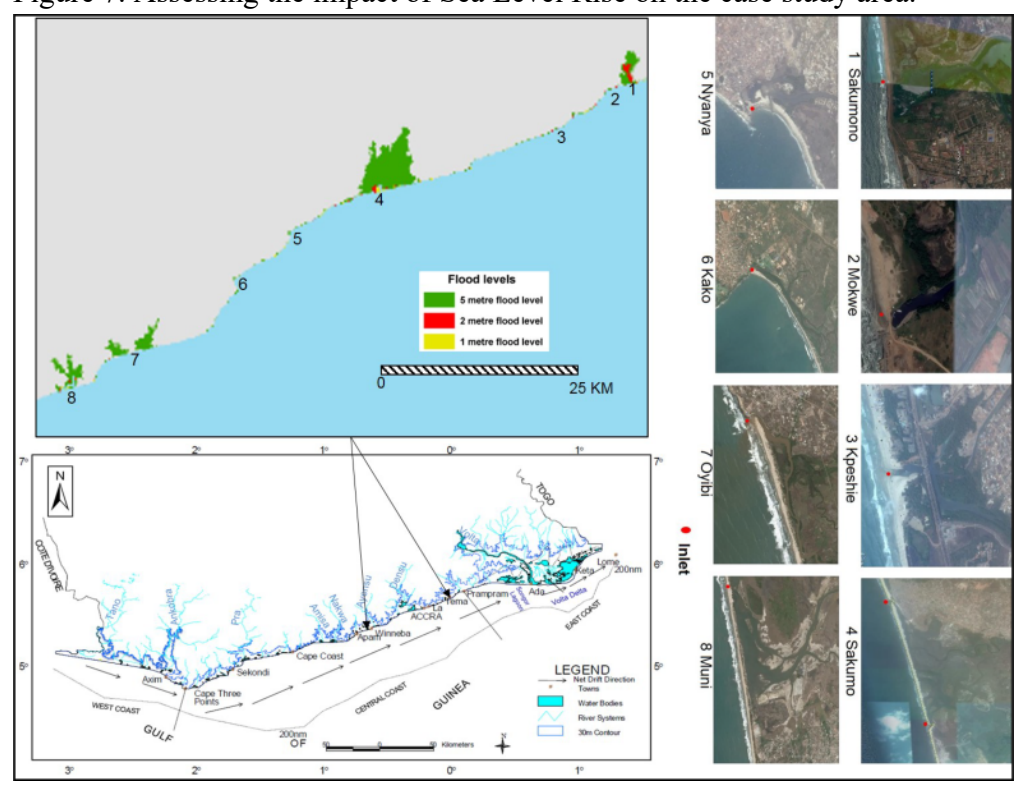

Figure 8. Assessing the impact of rainfall-induced flooding on the case study area.

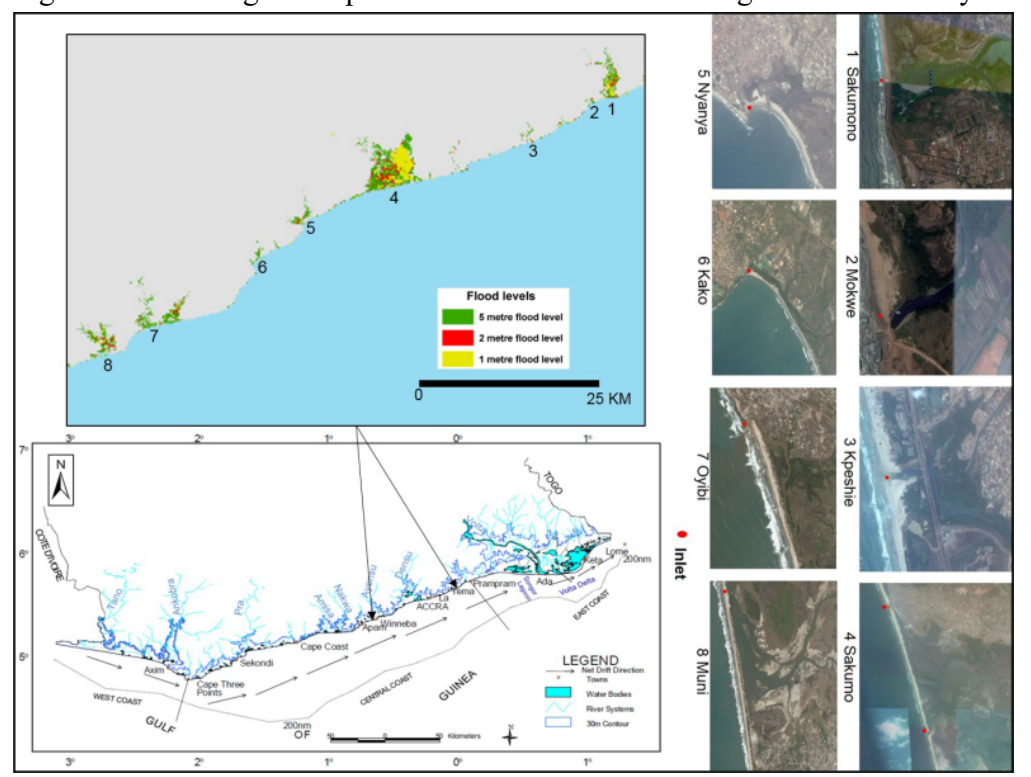

The outcome of the assessment shown in Figure 7 revealed that SLR, storm surge would have a significant impact on the lagoons and the intervening land at the backshore if they cause the water level to rise above $2 \mathrm{~m}$. Due to the 
barriers across the inlets, a rise in water level less than $2 \mathrm{~m}$ may not cause significant flooding in most of the lagoons. However, a rise in water level in the case of a storm surge will cause an episodic increase in barrier erosion and may overtop or breach the barrier, thereby allowing more seawater into the lagoons and possibly cause flooding at the backshore. Such an event may be risky to life and properties at the backshore. Lagoons 1, 4, 7 and 8 (Figure 7) may be very vulnerable to such scenarios. However, the water quality of those lagoons could be improved by such events because polluted lagoon water could be flushed out by lagoon-sea water exchanged before the barrier is sealed by wave action and longshore drift.

The rainfall-induced flood risk assessment (Figure 8) revealed that the case study area is more vulnerable to rainfall-induced floodwater from behind (the hinterland) than to seawater inundation from the seafront. This is because the back shores of the lagoon inlets tend to have elevations lower than the barrier foreshore. Therefore, any rainfall in the hinterland that causes runoff water to rise to $1 \mathrm{~m}$ or higher could cause significant flooding to properties near the lagoon inlets. All the lagoons are vulnerable to this problem except for lagoon 6 (Figure 8). This situation may be very injurious to the lagoon ecosystem, since the flood water may carry not only nutrients but also various contaminants and solid plastic waste into the lagoon channel (Mitchell, Boateng, and Couceiro 2017). Unfortunately, due to the barriers across the inlets such polluted runoff water may not be able to flush out to sea, thus impacting negatively on the water quality of the lagoons.

\section{Discussion}

Though the results outlined above relate to only a few lagoons and cover less than one year, they nevertheless enable some discussion about the impact $\mathrm{CC}$ will have on polluted lagoons and land-use at the backshore of the lagoonal coastline. Different activities are vulnerable to a greater or lesser extent to any effects of rising sea level, increased storminess and increased freshwater flows. The results highlight the need to develop and implement adaptation measures well in advance to reduce the anticipated impacts of CC on Ghana's coastal lagoons. The ever-growing coastal communities and the extremely high value of coastal assets in the coastal zone of Ghana and elsewhere suggest that poorly informed adaptation measures may have devastating effects, and in some situations, may even cause more damage than 'doing nothing' (Hoggart et al. 2014). Therefore, local-scale assessment of the impacts of CC in a coastal area like this paper should be undertaken in advance. This will enable effective and sustainable adaptation measures to be developed and implemented on time to reduce the negative impacts of CC and to enhance the positive ones for the benefit of coastal dwellers.

\section{Anthropogenic impact on coastal lagoons}

The field evidence presented in Figures 2-5 and the results from the water quality assessment show that anthropogenic factors are driving serious changes to Ghana's coastal lagoon ecosystems and the valuable services they provide to the environment and the local economy. In fact, water and coastal debris pollution particularly, ammonia, plastics and extraction of beach sand for construction were among the key factors that threaten the long-term sustainability of the coastal lagoon and associated ecosystem services in Ghana. The high ammonia and nitrate levels could reduce the quality of the lagoons as a fish spawning grounds. Plastic pollution and the beach sand mining are causing habitat destruction, mortalities and dwindling population of some coastal and marine species, particularly, sea turtles and ghost crab (Jonah et al. 2015; Formia et al. 2003). Their impacts are also affecting beach tourism and thus robbing the nation to some extent of recreational and other economic benefits from the coastal lagoons.

Furthermore, the depletion of the mangrove forest around the coastal lagoons is one problem, which could cause ecological damage to the lagoons and their ability to reduce some of the impacts of CC. Mangroves could contribute to the reduction of global warming and the effects of $\mathrm{CC}$ through carbon sequestration, flood assimilation and serving as a windbreak to reduce the impacts of a storm (Lloret et al. 2008; Anthony et al. 2009; Boateng 2018). Mangrove destruction and the pollution of coastal lagoons in Ghana are depleting fish spawning grounds, habitats, the feeding grounds of migratory birds and many coastal and marine species. It could also contaminate commercial fishing, harm to public health and increase the vulnerability to communities near the lagoons. Indeed, coastal lagoons in the study area were considered to be highly vulnerable to eutrophication, due to increasing population densities and consequent pollutions resulting from increasing waste production and the possible use of fertilizers for agriculture in the surrounding watershed. The high concentration of Ammonia observed in many of the lagoons (Tables 2 and 3) attest to 
this assertion. Ghana needs to develop a holistic approach to manage the anthropogenic activities that could combine with CC to worsen the predicted effects of CC.

\section{Impacts of CC on coastal lagoons}

$\mathrm{CC}$ is likely to alter the fragile ecosystem of coastal lagoons and the services they provide. CC effects including temperature rise, SLR, hydrodynamics changes, changes in water salinity, an increase in dissolved carbon dioxide, an increase in precipitation and an increase in the frequency of extreme weather events (Ranasinghe 2016). These effects, in combination with anthropogenic factors, could have deleterious impacts on coastal lagoon ecosystems in Ghana and other tropical regions, if appropriate interventions and adaptation measures are not implemented. The CC effects may also increase the appearance of eutrophication processes (Lloret et al. 2008; Anthony et al. 2009), coastal and marine species extinction and decline of both artisanal and industrial fisheries in West Africa (Belhabib, Lam, and Cheung 2016). The impacts of CC are likely to be geographically variable at both regional and local scale (Ward et al. 2016). This arguably indicates that the impacts of $\mathrm{CC}$ on coastal lagoons discussed in this paper may also occur in coastal lagoons in other tropical regions.

It is anticipated that $\mathrm{CC}$ will increase storm wave, storm surge, SLR and extreme rainfall flooding (Figures 7 and 8). These will result in more severe coastal erosion, particularly, at the barriers of closed lagoons. That may either close existing lagoon inlets through the accumulation of eroded materials in the inlets or open new inlets through erosion and breaching of the existing barrier that separates the lagoon from the sea. Closing an existing inlet and/or breaching new inlets will have massive implications on the tidal prism and hence water exchange between the ocean and the estuary/lagoon, which in turn will affect all estuarine processes (mixing, flushing, circulation and water quality (Ranasinghe 2016; Mitchell, Boateng, and Couceiro 2017). The increased erosion of lagoon barriers, rising sea levels and storm surges could result in submergence and disappearance of many coastal lagoons along the coast of Ghana.

Evidence from local newspaper reports indicates that Ghana is already experiencing the devastating effects of CC. Some coastal lagoons and settlements have already disappeared (Bokpe 2016; Myjoyonline 2016). This problem might not be limited to lagoons in Ghana alone, but could affect many coastal communities in West African countries. Indeed, most of the capital towns and commercial cities of maritime countries in West Africa such as Cotonou-Benin, Lome-Togo, Legos-Nigeria, Duala-Cameroon, Abidjan-Cote d'Ivoire, Monrovia-Liberia, Freetown-Serra Leone and Banjul-Gambia are located at the precincts of barrier lagoons. These towns and cities may be exposed to the devastating effects of CC if proper adaptation measures are not implemented.

Effects of CC could alter the favorable conditions for the growth and survival of lagoon mangroves. Increase storminess and erosion could damage many coastal lagoon mangroves. Rise in temperature, prolong the dry season and alternate high rainfall will either cause loss of coastal wetland or decrease in their productivity (Arnell et al. 2016). This could affect economic, social and recreational use of coastal lagoons in Ghana, thus limiting their contributions to the sustenance of the local people. It is worth noting that if proper waste management practices are not implemented in the settled areas like Tema, Accra and Winneba, the increased rainfall and the ensuing flooding will not only risk life and expensive properties in the urban areas of Accra (Asumadu-Sarkodie, Asantewaa, and Herath 2015; Amoako 2016; Fox 2016), but also it will transport lots of harmful waste materials and plastics into the coastal environment and thus exacerbating the ecological damage and impacts on public health (Figures 3 and 4).

Furthermore, $\mathrm{CC}$ could have some positive impacts on coastal Lagoons. The sea-level rise and associated increased storminess will undoubtedly affect the flushing of lagoons particularly, the barrier lagoon systems. This may bring some optimism because the increased flushing the lagoons would dilute the anthropogenic pollutants and improve the water quality. Conversely, sea-level rise could cause a change in the sediment dynamics along the shoreline as a consequence of hydrological change, leading to higher and wider barriers and reduced exchange with the sea. This could make a 'cleaner' fishing lagoons become more like Lagoon 2 with its potential for eutrophication and the accompanying reduction in ecological status. This study shows the need for an integrated water quality strategy including standards and enforcement, particularly if the aim is to increase recreational use of lagoons and other revenues and to maintain the fishing revenues that are currently so important in coastal areas. There is a further related need to ensure that any discharge consenting process for the outlets from sewage treatment works, for example, takes better account of the local coastal flushing characteristics of the lagoons. 


\section{Management and adaptat on strategies}

The predicted future impacts discussed above may not be exclusively caused by either the anthropogenic activities or the CC drivers. Rather, it is the combination of both impacts that will cause a damaging effect on coastal lagoon ecosystems and reduce their services to society and the natural environment. CC mitigation and adaptation policies should, therefore, consider anthropogenic drivers as well. Any CC adaptation measures in Ghana and elsewhere that do not seek to reduce the harmful anthropogenic activities in the coastal zone may not succeed.

Traditionally, spatial planning policies that control anthropogenic development in the coastal zone of Ghana and elsewhere were developed with inadequate knowledge of CC impacts and therefore, CC adaptation measures were not considered. In order to ensure that $\mathrm{CC}$ adaptation strategies cover the effects of both anthropogenic and environmental change, spatial planning and CC adaptation policies should be integrated (Boateng 2008). Such integration will lead to zoning coastal areas based on vulnerability and guide present and future development away from vulnerable coastal lands, secure coastal buffer lands and protect wetlands with conservation interest. Boateng, Wiafe and Jayson-Quashigah, (2016) suggest the implementation of management policies that allow for future flexibility in response to changes in physical conditions and socio-economic circumstances of vulnerable coastlines. The integration of CC adaptation into local spatial planning policies could encourage critical thinking about the most appropriate and sustainable measures needed at present and future adaptation. This process could lead to the conser-vation of wetlands, mangroves, heritage and other special sites of scientific interest. It could also lead to the develop-ment of holistic shoreline management planning, which will prevent the "knock-on-effects" of the present site-specif-ic, interventions that tend to stabilize a section of the coastline and translate the problem down-drift.

Many authors including Nicholls et al. 2007; IPCC 2014; Cloern et al. 2016, have suggested different CC adaption measures based on recent extreme events and their impacts on coastal systems and related communities. However, any management strategies for lagoons of these type need to be reinforced by decision-making structures that are agreed with all stakeholders involved. The proposed adaptation methods must account for a wide variety of different understanding and conceptualisations of the coastal system, but must nevertheless be sufficiently straightforward to allow participation by all interested parties. Lessons could be learned in this respect from other similar recent cases (de Santo 2016), where adaptation to change only comes about when all parties are working toward the same common goals. As always, a combination of good science and effective management (Runhaar, van der Windt, and van Tatenhove 2016), with each reinforcing the other, is likely to be instrumental in achieving an outcome that benefits all parties.

We proposed the results from this study could be used as a baseline for the development of management and adaption strategies. The following adaptation measures to reduce future risks in Ghana and elsewhere with similar coastal lagoons are hereby proposed:

- Educate the local lagoon communities on the benefit of good lagoon water quality and the need to contribute to the maintenance of good water quality in the lagoons. They also need education on storm wave, storm and flood awareness. This will ensure effective community stewardship of the lagoons improve their preparedness to response coastal hazard associated with CC thereby reducing community vulnerability;

- Create a forum that enables lagoon communities and other stakeholder groups to meet and discuss issues affecting the lagoons, assesses options for management and to share best practices;

- Develop an early warning and response system to forecast extreme weather events to reduce death and destruction to artisanal fishing gear and properties at the backshore of lagoons;

- Develop a flood alleviation schemes such as flood gate, embankment, flood storage and sustainable drainage systems (Woods-Ballard et al. 2007; Jose, Wade, and Jefferies 2015) to protect barrier lagoon and the intervening settlements.

- Develop an elevated storm shelter with storage facility for food and medicine in the highly vulnerable areas where evacuation may be impossible in an extreme weather condition (particularly, lowlying lagoon area); 
- Establish policies to conserve coastal landforms, mangroves and wetland ecosystems to provide healthy spawning grounds, flood assimilation and protection from storm surges to reduce the impact on livelihoods, life and properties;

- Engage plastic bottled and beverage manufacturers to develop and implement sustainable waste management practices that are based on the principles of reducing, reuse and recycle to curtail the problem of coastal debris.

- Strengthen the national disaster management strategy and governance for effective disaster prevention, adequate public preparedness and response;

- Pursue policies of coastal setback lines/buffer zones and implement coastal defence scheme that strengthens the natural defenses. Due to uncertainties in the climate variability, discourage hard engineering schemes that tend to reduce the present use and benefits of the beach environment.

\section{Conclusions}

The authors believe that investigation about the effects of climate change on vulnerable coastal systems in a tropi-cal environment required considerable caution due to the deficiency of predictability and the effects of extreme weather conditions. There is much about the coastal environment that remains unpredictable in terms of scale and rate of change. Nevertheless, it is possible to make some statements about the likely effects of climate change for the case of Ghana's coastal lagoons, where much of the coastal zone is characterized by low lying areas, fronted by a sandy beach held in position by rocky headlands, with the presence of brackish or freshwater lagoons enclosed by the barri-er beach, provide such an important resource to local communities and for the ecosystem. The paper concludes that though anthropogenic actives are the key factors currently impacting negatively on the sampled lagoons, the effects of climate change could combine with the impacts of the present human actives to destroy the lagoons sooner than anticipated. The paper, therefore, recommends the development and implementation of sustainable coastal lagoon management and adaptation strategies now to mitigate and prevent the serious future impact of climate change.

\section{References}

Affam, M., and D. N. Asamoah. 2011. Economic potential of salt mining in Ghana towards the oil find. Research Journal of Environmental and Earth Sciences 3 (5):448-56.

Amoako, C. 2016. Brutal presence or convenient absence: The role of the state in the politics of flooding in informal Accra. Geoforum 77:5-16. doi: 10.1016/j.geoforum.2016.10.003.

Anthony, A., J. Atwood, P. August, C. Byron, S. Cobb, C. Foster, C. Fry, A. Gold, K. Hagos, L. Heffner, et al. 2009. Coastal lagoons and climate change: Ecological and social ramifications in U.S. Atlantic and Gulf coast ecosystems. Ecology and Society 14 (1):8. doi: 10.5751/ES-02719-140108.

Appeaning Addo, K., M. Walkden, and J. P. Mills. 2008. Detection, measurement and prediction of shoreline reces-sion in Accra, Ghana. Isprs Journal of Photogrammetry and Remote Sensing 63 (5):543-58. doi: 10.1016/ j.isprsjprs.2008.04.001.

Arnell, N. W., S. Brown, S. N. Gosling, P. Gottschalk, J. Hinkel, C. Huntingford, B. Lloyd-Hughes, J. A. Lowe, R. J. Nicholls, T. J. Osborn, et al. 2016. The impacts of climate change across the globe: A multi-sectoral assessment. Climatic Change 134 (3):457-74. doi: 10.1007/s10584-014-1281-2.

Asumadu-Sarkodie, S., O. P. Asantewaa, and J. M. P. C. Herath. 2015. Flood risk management in Ghana: A case study in Accra. Advances in Applied Science Research 6 (4) :196-201.

Belhabib, D., V. W. Y. Lam, and W. W. L. Cheung. 2016. Overview of West African fisheries under climate change: Impacts, vulnerabilities and adaptive responses of the artisanal and industrial sectors. Marine Policy 71:15-28. doi: 10.1016/j.marpol.2016.05.009.

Blumenthal, J. U., D. D. Mara, A. Peasey, G. Ruiz-Palacios, and R. Stott. 2000. Guidelines for the microbiological quality of treated wastewater used in agriculture: Recommendations for revising WHO guidelines. Bulletin of the World Health Organization 78 :1104-16.

Boateng, I. 2010. Spatial planning in coastal regions: Facing the impact of climate change. Report of FIG Commis-sion 8 Working Group 8.4, Copenhagen: The International Federation of Surveyors (FIG), Publication No. 55. 
Boateng, I. 2008. Integrating sea-level rise adaptation into planning policies in the coastal zone. In Proceedings of the In-ternational Federation of Surveyors Working Week and XXXI General Assembly 2008- Integrating Generations, TS 3F, Stockholm, 14-19 June 2008. ISBN 978-87-90907-67-9.

Boateng, I. 2009. Development of integrated shoreline management planning: A case study of Keta, Ghana. In FIG Working Week 3-8 May 2009. TS 4E - Coastal Zone Management. Surveyors Key Role in Accelerated Development, Eilat, Israel.

Boateng, I. 2012a. An assessment of the physical impacts of sea-level rise and coastal adaptation: A case study of the eastern coast of Ghana. Climatic Change 114 (2):273-93. vol 20, doi: 10.1007/s10584-011-0394-0.

Boateng, I. 2012b. An application of GIS and coastal geomorphology for large scale assessment of coastal erosion and management: A case study of Ghana. Journal of Coastal Conservation 16 (3):383-97. doi: 10.1007/ s11852-012-0209-0.

Boateng, I. 2018. An assessment of vulnerability and adaptation of coastal mangroves of West Africa in the face of climate change. In Threats to mangrove forests: Hazards, vulnerability, and management, ed. C. Makowski and C. W. Finkl. Springer International Publishing. doi: 10.1007/978-3-319-73016-5.ISBN: 978-3-319-73015-8.

Bokpe, S. J. 2016, February 2. Sea erosion steadily wiping out 5 Keta communities. Graphic Online. http:// www.graphic.com.gh/news/general-news/sea-erosion-steadily-wiping-out-5-keta-communities.html.

Cloern, J. E., P. C. Abreu, J. Carstensen, L. Chauvaud, R. Elmgren, J. Grall, H. Greening, J. O. R. Johansson, M. Kahru, E. T. Sherwood, et al. 2016. Human activities and climate variability drive fast-paced change across the world's estuarine-coastal ecosystems. Global Change Biology 22 (2):513-29. doi: 10.1111/gcb.13059.

DeConto, R. M., and D. Pollard. 2016. Contribution of Antarctica to past and future sea-level rise. Nature 531 (7596):591-7. doi: 10.1038/nature17145.

Entsua-Mensa, M. 2002. The contribution of coastal lagoons to the continental shelf ecosystem of Ghana. The Gulf of Guinea large marine ecosystem. Elsevier. Science B.V. Vol. 11 pp 161-169. https://doi.org/10.1016/ S1570-0461(02)80035-0

Formia, A., M. Tiwari, J. Fretey, and A. Billes. 2003. Sea Turtle Conservation along the Atlantic Coast of Africa. Marine Turtle Newsletter 100:33-7.

Fox, E. 2016. Floods leave many dead in southern Ghana: Deadly downpours cause widespread flooding along the Cape Coast as the West African wet season intensifies. http://www.aljazeera.com/news/2016/06/floodsleave-dead-southern-ghana-160616104330811.html

Glavovic, B. C. 2000. Our coast, our future: A new approach to coastal management in South Africa. Cape Town: Department of Environmental Affairs and Tourism.

Hallegatte, S., N. Ranger, O. Mestre, P. Dumas, J. Corfee-Morlot, C. Herweijer, and R. M. Wood. 2011. Assessing climate change impacts, sea-level rise and storm surge risk in port cities: A case study on Copenhagen. Climatic Change 104 (1):113-37. doi: 10.1007/s10584-010-9978-3.

Hoggart, S. P. G., M. E. Hanley, D. J. Parker, D. J. Simmonds, D. T. Bilton, M. Filipova-Marinova, E. L. Franklin, I. Kotsev, E. C. Penning-Rowsell, S. Rundle, et al. 2014. The consequences of doing nothing: The effects of seawater flooding on coastal zones. Coastal Engineering 87:169-82. doi: 10.1016/ j.coastaleng.2013.12.001.

IPCC. 2014. Climate change: Impacts, adaptation, and vulnerability. Part A: Global and sectoral aspects. Contribution of Working Group II to the Fifth Assessment Report of the Intergovernmental Panel on Climate Change. Cambridge: Cambridge University Press.

Jamieson, R. C., R. J. Gordon, K. E. Sharples, G. W. Stratton, and A. Madani. 2002. Movement and persistence of faecal bacteria in agricultural soils and subsurface drainage water: A review. Canadian Biosystems Engineering Can-ada 44:(1) pp1-9.

Jevrejeva, S., A. Grinsted, and J. C. Moore. 2014. Upper limit for sea-level projections by 2100. Environmental Re-search Letters 9 (10):104008. doi: 10.1088/1748-9326/9/10/104008. 
Jonah, F. E., D. W. Aheto, D. Adjei-Boateng, N. W. Agbo, I. Boateng, and M. J. Shimba. 2015. Human use and modification of beaches and dunes are linked to ghost crab (Ocypode spp) population decline in Ghana. Regional Studies in Marine Science 2:87-94. doi: 10.1016/j.rsma.2015.08.013.

Jose, R., R. Wade, and C. Jefferies. 2015. Water Science \& Technology, Smart SUDS: Recognising the multiple-benefit potential of sustainable surface water management systems. Water Science and Technology : A Journal of the International Association on Water Pollution Research 71 (2):245-51. doi: 10.2166/wst.2014.484.

Kjerfve, B. 1994. Coastal lagoon processes. Amsterdam, The Netherlands: Elsevier.

Lloret, J., A. Mar'In, and L. Mar'In-Guirao. 2008. Is coastal lagoon eutrophication likely to be aggravated by global climate change? Estuarine, Coastal and Shelf Science 78 (2):403-12. edoi: 10.1016/j.ecss.2008.01.003.

Millennium Ecosystem Assessment. 2005. Ecosystems and human well-being: Synthesis. Washington, DC: Island Press

Mitchell, S., I. Boateng, and F. Couceiro. 2017. Influence of flushing and other characteristics of coastal lagoons using data from Ghana. Ocean \& Coastal Management Xxx 143:26-12. doi: 10.1016/j.ocecoaman.2016.10.002.

Myjoyonline. 2016, September 5. Accra fishermen count losses after storm waves destruction. http://www.myjoyonline.com/news/2016/September-5th/accra-fishermen-count-losses-after-tidal-waves-destruction.php.

NASA. 2015. Global climate change. http://climate.nasa.gov/vital-signs/sea-level/

Nicholls, R. J., P. P. Wong, V. R. Burkett, J. O. Codignotto, J. E. Hay, R. F. McLean, S. Ragoonaden, and C. D. Woodroffe. 2007. Coastal systems and low-lying areas. Climate Change 2007: Impacts, Adaptation and Vulnerability. Contribution of Working Group II to the Fourth Assessment Report of the Intergovernmental Panel on Climate Change, ed. M. L. Parry, O. F. Canziani, J. P. Palutikof, P. J. van der Linden, and C. E. Hanson, , 315-56. Cambridge, UK: Cambridge University Press

Nicholls, R. J., S. Hanson, J. A. Lowe, R. A. Warrick, X. Lu, and A. J. Long. 2014. Sea-level scenarios for evaluating coastal impacts. Wiley Interdisciplinary Review: Climate Change 5 (1):29-150.

Permanent Service for Mean Sea Level (PSMSL). 2013., Takoradi. http://www.psmsl.org/data/obtaining/stations/ 331.php\#docu.

Pfeffer, W. T., J. T. Harper, and S. O. Neel. 2008. Kinematic constraints on glacier contributions to 21st-century sealevel rise. Science 321 (5894):1340-3. doi: 10.1126/science.1159099.

Ranasinghe, R. 2016. Assessing climate change impacts on open sandy coasts: A review. Earth-Science Reviews 160 (2016):320-32. doi: 10.1016/j.earscirev.2016.07.011.

Runhaar, H. A. C., H. J. van der Windt, and J. P. M. van Tatenhove. 2016. Productive science-policy interactions for sustainable coastal management: Conclusions from the Wadden Sea area. Environmental Science \& Policy 55:467-71. doi: 10.1016/j.envsci.2015.09.002.

Santo, D. E. M. 2016. Assessing public "participation” in environmental decision-making: Lessons learned from the UK Marine Conservation Zone (MCZ) site selection process. Marine Policy 64, 91-101.

Stoddard, C.S., Coyne, M.S. and Grove, J.H., 1998. Fecal bacteria survival and infiltration through a shal-low agricultural soil: timing and tillage effects. Journal of environmental quality, 27(6), pp.1516-1523.

Tol, R. S. J., R. J. T. Klein, and J. R. Nicholls. 2008. Towards successful adaptation to sea-level rise along Europe's coasts. Journal of Coastal Research 242 (2):432-42. doi: 10.2112/07A-0016.1.

Ukwe, C., C. Ibe, and K. Sherman. 2006. A sixteen-country mobilization for sustainable fisheries in the Guinea Current Large Marine Ecosystem. Ocean \& Coastal Management 49 (7-8):385-412. doi: 10.1016/j.ocecoaman.2006.04.006.

Vaughan, D. G. 2008. West Antarctic ice sheet collapse-The fall and rise of a paradigm. Climatic Change 91 (12):65-79. doi: 10.1007/s10584-008-9448-3.

Ward, R. D., D. A. Friess, R. H. Day, and R. A. MacKenzie. 2016. Impacts of climate change on mangrove ecosystems: A region by region overview. Ecosystem Health and Sustainability 2 (4):e01211. doi: 10.1002/ehs2.1211.

Woods-Ballard, B., R. Kellagher, P. Martin, C. Jefferies, R. Bray, and P. Shaffer. 2007. The SUDS manual. London: CIRIA. 